\title{
Research on Teaching Reform of Basic Courses of Landscape Architecture Design in Applied Universities
}

\author{
Yan Zhou, Lei Fan* \\ Yanbian University, 133002
}

Supported by the Educational Science Planned Research Project of 13th Five-year Plan of Jilin Province in 2016 (Grant No. GH16029), the Educational Science Planned Research Project of 13th Five-year Plan of Jilin Province in 2017 (Grant No. GH170022), the Research Project of Higher Education Research Academy of Jilin Province in 2017 (Grant No. JGJX2017C8), the Research Project of Higher Education Research Academy of Jilin Province in 2018(Grant No. JGJX2018D363), the PhD Start-up Fund of Yanbian University (Grant No. 602018022)the Schoolenterprise Cooperation Fund of Yanbian University (Grant No. 482019011), Youth Fund Project of Yanbian Univ ersity (Grant No.602016029), and the Excellent Course Construction Project of Yanbian University.

Abstract: Design foundation is an introductory course for landscape architecture majors, and it occupies a very important position in the entire landscape architecture professional teaching. This article is mainly based on the relevant requirements of application-oriented talent training, combined with the current teaching status of landscape architecture design professional courses, analyzes the problems in actual teaching, and makes some adjustments in the teaching content to reform the basic courses of landscape architecture design. The teaching method enhances the enthusiasm of students to learn, and lays a solid foundation for cultivating outstanding applied design talents.

Keywords: Higher Education; Landscape Architecture Design; Basic Course Teaching; Reform Research

The so-called application-oriented colleges and universities are training applied professionals who meet the needs of current social development. In the teaching of landscape architecture, this teaching concept allows students to have both solid basic professional knowledge and good professional practice capabilities., Gradually improve students' ability to discover and solve problems, and effectively improve the teaching quality and efficiency of landscape architecture design.

\section{Problems in the teaching of landscape architecture design majors}

\subsection{The phenomenon of emphasizing theory and neglecting practice in teaching is serious}

Compared with traditional teaching methods, applied teaching methods emphasize the training of students' practical application ability. However, in actual teaching, most teachers still use traditional teaching methods, with teachers as the center of teaching, and the phenomenon of emphasizing theory and neglecting practice is still serious. In addition, influenced by the concept of exam-oriented education, the overall teaching atmosphere is too rigid, and it is difficult to effectively enhance students' interest in learning. Students lack initiative and creativity, which leads to a disconnect between theoretical knowledge and practical application, which is very unfavorable for students' subsequent integration Development does not meet the training requirements of applied talents.

\subsection{The actual teaching content is not closely related to the current industry development}

Nowadays, with the continuous acceleration of the construction process of modern cities, the requirements for landscape design disciplines are getting higher and higher. Coupled with the continuous development of various basic Copyright (C) 2020 Yan Zhou et al

doi: 10.18282/le.v9i6.1341

This is an open-access article distributed under the terms of the Creative Commons Attribution Non-Commercial License

(http://creativecommons.org/licenses/by-nc/4.0/), which permits unrestricted non-commercial use, distribution, and reproduction in any medium, provided the original work is properly cited. 
disciplines, there are new contents in the landscape design disciplines at all times. Update, so teachers should make the teaching content forward-looking and exploratory when teaching landscape design. However, most design majors did not highlight this feature in actual teaching. The course items lack authenticity, the design content does not match the actual job content, too much attention is paid to the details of the design process, and the project is less considered. Operability makes the teaching content out of the demand of actual industry development, which is very detrimental to the subsequent development of students.

\subsection{The content of professional course assessment is not reasonable enough}

A standardized course evaluation system can reflect students' learning attitudes and learning effects more intuitively. However, most of the research on the evaluation methods of landscape design majors is too traditional and emphasizes the evaluation of the effect of design drawings. The behavioral performance is integrated into it. It is difficult for students to fully understand their own level in a single assessment content. An overly one-sided evaluation can easily cause a blow to students' learning enthusiasm, which not only seriously hinders the development of students' innovative thinking ability, but also affects teachers' follow-up teaching The goal design and the planning of teaching content have had a great impact.

\section{Teaching reform measures of applied landscape architecture design basic courses}

\subsection{Adopt innovative teaching methods to improve classroom teaching efficiency}

A good teaching method is an effective way to achieve the teaching goal. In the basic course of landscape design, teachers should take the cultivation of students' practical application of knowledge as the core goal of teaching, and use a variety of innovative teaching methods to achieve this. Nowadays, the typical innovative teaching method is the "dual subject" classroom teaching model. The core of its content is to make teachers in the main position of the teaching process and students in the main position of the learning process. The two complement each other and work together. According to this The teaching methods extended by the teaching philosophy are as follows: First, the brainstorming teaching method. Its characteristic is to guide students to think independently, improve students' ability to find and solve problems, change the traditional teaching method with teachers as the main body of classroom teaching, and effectively activate students' innovative thinking. Second, feedback learning pedagogy. This method enhances the feedback teaching link in the design process, and uses this to deepen the communication and exchanges between teachers and students, so that teachers can actively participate in student design, and prompt students to understand their own shortcomings more quickly. Effectively improve students' knowledge application ability.

\subsection{Establish a new teaching system based on applied talents}

The traditional design teaching method mainly reflects the students' learning effect through the evaluation of the student's project design. The evaluation emphasizes the standardization of the design work and the effect of the picture. It is easy for students to form a certain mindset. Conducive to the development of students' independent thinking and innovative thinking. Therefore, in the specific teaching process, teachers should take the cultivation of students' application-oriented talents as the teaching orientation, pay attention to basic theoretical knowledge, and cultivate students' flexible and innovative thinking as much as possible. Combining the actual situation of teaching, the teaching content is close to the actual life of the students, so that students have a sense of substitution, and it is convenient for students to understand and use. In addition, classic cases in the industry should be frequently cited in teaching, so that students can understand the latest development direction of the industry and the aesthetic needs of the market, so that students can have an accurate positioning of their own abilities and clarify their future learning goals. Improve the effect of garden design classroom teaching.

\subsection{Improve the evaluation system of garden design teaching}

First of all, in the assessment content, the proportion of design drawings should always be appropriately reduced. The pre-design thinking plan and work process should be integrated into the content that can reflect the students' comprehensive ability, and the focus of the assessment should be biased towards the students' comprehensive ability 
evaluation, so that The ability of students can be more comprehensively reflected. Secondly, use diversified evaluation methods, highlight practical content evaluation, rebuild the evaluation team in the project evaluation process, and include students, teachers, in-service designers and other personnel to evaluate students' design content from multiple perspectives, so that The overall evaluation system has become more objective.

\section{Conclusion}

Applied colleges and universities should adopt innovative teaching methods in the teaching process of landscape design courses, pay attention to the cultivation of students' practical application ability, optimize the course explanation process, clarify teaching goals according to the actual situation of students, promote effective communication between teachers and students, and improve Garden design teaching evaluation system, build a good learning environment, and cultivate more application-oriented professional designers for the society.

\section{References}

1. Wang Xiaoxiao, Tang Haiyan, Zhang Zhiwei, et al. Research on the teaching reform of landscape architecture design courses in applied colleges and universities[J]. Modern Horticulture, 2019, 000(010):230-231.

2. Sun Le. Some thoughts on the teaching reform of landscape design courses for environmental design majors in applied universities [J]. Science \& Technology Information, 2019, 017(028):82-83.

3. Huang Dexin. Exploration on the Teaching Reform of Landscape Design Course of Environmental Design Major in Applied Universities[J]. Journal of Liaoning Institute of Science and Technology, 2018, 020(004): 92-95. 